\title{
GENERAL ANESTHESIA: IS IT SAFE FOR NEWBORNS, INFANTS AND YOUNG CHILDREN?
}

\author{
Nancheva Jasminka, ${ }^{1}$ Andonovski Alan, ${ }^{1}$ Kamnar Victor, ${ }^{1}$ Georgieva Daniela, ${ }^{1}$ \\ Nanceva Andrea, ${ }^{2}$ Georgiev Antonio ${ }^{3}$ \\ ${ }^{1}$ University Clinic for Orthopaedic surgery, Clinical Center "Mother Teresa", Medical Faculty, \\ University "St. Kiril and Metodij”, Skopje, R. Macedonia \\ 2 General Hospital "8 mi Septemvri", Skopje, R. Macedonia \\ ${ }^{3}$ PHO Cardiology - Prima, MIT University, Skopje, R. Macedonia
}

Primljen/Received 01. 03. 2016. god.

Abstract: The exposure of neonates, infants and small children to general anesthesia is becoming a common occurrence.Accumulating preclinical data indicate that exposure to commonly used general anesthetic agents during key periods of brain developmentin this population (between late gestation and 3 to 4 years of age), can lead to apoptotic neurodegeneration, synapse loss, and cognitive and neurobehavioral deficits that persist as the organism matures. New work suggests that infants and small children undergoing some types of surgery could have better recovery if they receive regional anesthesia rather than general anesthesia. In response to this concerns, the Food and drug administration (FDA) and the International Research Society in anesthesia (IARS) started an initiative called Smart Tots (Strategies for Mitigating Anesthesia- related neuro Toxicity in Tots)which examine the effects of anesthesia on brain development.Also another two major prospective studies are ongoing in children: PANDA (Pediatric Anesthesia Neurodevelopment assessment Study) project is a large, multi-center study based at the Morgan Stanley Children's Hospital of New York at Columbia University, and another one is GAS study which is a multisite randomized controlled trial comparing neurodevelopment outcomes in infant receiving general anesthesia compared to spinal and other regional anesthetics to the stress response to surgery.

The findings from these studies will help researches to design the safest anesthetic regimens and to develop the new and safer anesthetic drugs for use in pediatric medicine.

Keywords: pediatric anesthesia, newborn, infant, small children, neurotoxity risk, neurocognitive outcome.
Prihvaćen/Accepted 06. 05. 2016. god.

\section{INTRODUCTION AND CONTEXT}

The exposure of newborns, infants and very young children to general anesthesia is becoming a common occurrence. The frequency of operating suite visits has increased, as have the lengths of stay in intensive care units, resulting in the annual administration of many millions general anesthetics to the pediatric patient population (1).

In newborns and infants morbidity and mortality from general anesthesia is higher than in adults, in infants is higher than in premature and those with body weight $<2 \mathrm{~kg}$ compared with newborns at term. Newborns are at greater risk to infants while they are at higher risk to children and of course smaller children compared to older children and adults. These correlations resulting among other things, and from the differences in anatomical and physiological features between newborn, infants and small children. Consistently cited as one of the greatest discoveries of modern medicine, general anesthesia has garnered widespread respect and acceptance for its remarkable ability to safely render a person unconscious with nothing to show for it afterward but a short-lived hangover. However, begining approximately a decade ago, studies began to challenge the premise that the brain is restored to its erstwhile pristine state after general anesthesia. Nowhere is the possibility of long-term alteration in brain function of greater concern than when an infant needs a procedure that requires general anesthesia. Accumulating preclinical data indicate that exposure to commonly used general anesthetic agents during key periods of brain development can lead to apoptotic neurodegeneration, synapse loss, and cognitive and behavioral deficits that 
persist as the organism matures $(2,3)$. In addition, neonatal anesthetic exposure alters neurogenesis and synaptogenesis in animals $(4,5)$, indicating that anesthetic medications influence neuroplasticity (6). The brain is most vulnerable to this neurotoxicity and neuroplasticity during the brain growth spurt, which corresponds to a critical period of synaptogenesis and activity-dependent pruning and sculpting of synaptic architecture $(2,3)$. Because synaptogenesis in humans is believed to occur between late gestation and 3 to 4 years of age, than newborns, infants and small children who require general anesthesia during these years are possibly at risk for cognitive or neurobehavioral sequelae, if the animal data can be extrapolated to humans.

\section{Anesthetic agents used for premedication, general anesthesia and pain treatment in new born, infant and small children}

\section{Premedication}

Recommendations forpremedicationofpediatric patientsvary widely. Basicallyapremedication with sedativesis not practicedfor newbornsand infantswith severeclinical picture. Atanxiety children are indicated giving Midazolam $0,1-0,15 \mathrm{mg} / \mathrm{kg}^{-1}$ i.m or per os in the form of syrup. Preoperative intramuscular atropine as anticholinergic is justified by the following: reducing bradycardia and hypotension in induction and during anesthesia in newborns and infants up to 3 months, also acts antisialogenic by reducing the secretion, thereby facilitating intubation. Also atropine is recommended to be given in neonates and infants operated under neuroaxialblocks. It is given in doses of $0.15-0.2 \mathrm{mg} / \mathrm{kg}^{-1}$ i.m, some anesthesists practice to give intravenously immediately before induction of anesthesia, and some only if bradycardia appear $(7,8)$.

\section{General anesthesia}

General anesthesia in these population are applied with intravenous or inhaled technique. Intravenous induction is indicated if the newborn or infant is delivered by intravenous cannula. Barbiturate is given with a rapid onset of action (for newborn thiopental $3 \mathrm{mg} / \mathrm{kg}^{-1}$ infant $\left.5 \mathrm{mg} / \mathrm{kg}^{-1}\right)$ or propofol $\left(2-3 \mathrm{mg} / \mathrm{kg}^{-1}\right)$. Propofol as hypnotic is allowed to be given in infants older than 1 month, but there are studies of newborn and premature where it is used as a hypnotic for induction and maintenanceof anesthesia $\left(1.0 \mathrm{mg} / \mathrm{kg}^{-1}\right)$. In infants the doses of propofol are higher, because of the large volume of distribution and faster decomposition. The appearance of hypotension and cardio-circulatory instability is a negative side effectof this hypnotic $(9,10)$. In newborn and infant analgesia during intravenous anesthesia can be established by using remifentanyl or fentanyl. As a opioids especially fentanyl in these patients may produce respiratory depression (residual effect) and usually practiced applying it, if premature or infant goes on a ventilator after surgery. Because propofol known to give cardio-circulatory instability it may be combined with ketamine (ketofol), in order to reduce the possibility of hypotension. Often in newborns with certain malformations are indicated intubation in live, but this is only possible if the infant has inserted intravenous cannula for possible complications (laryngospasm, bronchospasm). If the newborn has no intravenous cannula we tried to insert it by using few breaths of $7-8 \%$ sevoflurane -potent volatile anesthetic gas. The intubation are performed by using sevoflurane and intravenously by using depolarizing (succinylcholine) or non-depolarizing (rocuronium bromid, vecuronium bromid) muscle relaxant. In newborns and infants isoflurane and desfluranot do not find their place, because they are stronger, more iritable at induction in anesthesia (can be given cough, apnea, laryngospasm). Gas anesthesia alone does not make for itself a remarkable intraoperative analgesia and therefore need to be supplement with analgesic anesthetic (remifentanyl or fentanyl). Routinelyfor postoperative painacetaminophen is analgesic of choice, which should not be given more than 3 days because of its hepatotoxicity.

Waking from anesthesia requires reversing the block, breathing, grimacing, crying, attempted to selfextubation.

Postoperative apnea is serious problem in the newborn, especially if there is a history of prematurity, apnoic previous episodes, bradycardia, congenital defect, anemia, chronic lung disease (respiratory distress syndrome). Infants have a lower rate of Type 1 fibers and are at risk for fatigue. Residual anesthetic agents from operative intervention can also give apnea. Treatment consists of using tactile stimulation, oxygen support, use of caffeine, methylxanthines, and if it more frequent, endotracheal intubation and mechanical ventilation are required $(8,9,10)$. In these newborns if the operative procedure is on lower extremities or lower part of abdomen, neuroaxial blocks(spinal, caudal, epidural) are regional technique of choice.

\section{In recent years, the question is whether anesthesia for newborns, infants and young children is harmful?}

Concerns about the potential impact of general anesthesia on brain development appeared about 10 years ago, when in certain studies of young animals exposed to anesthesia has been shown that there are changes in the brain that are associated with behavior prob- 
lems. In these studies it has been shown that anesthetics which are usually used in anesthesia performed inhibition of neural activity through the disruption of synaptic transmission (depression of the nervous activity and decay of apoptotic cells) including GABA $(\uparrow$ receptor activity) and NMDA receptors (blockade) (6). In May 2015 American Society of Anesthesiologists has published the first on line edition of the official medical journal of Anaesthesiology which were publicized two studies from Royal Children Hospital, Melbourne, Australia,involving infants with hernia repair operated under the general and regional- spinal anesthesia. Experts examined the effects of general anesthesia in infants and young children and believe that these patients undergoing general anesthesia several times in the first three years of life, may beathigher risk in the development and learning difficulties. When it showed that the possibility of complications postoperative apnea and breathing complications are much lower in the group of infants operated under spinal anesthesia (11, 12, 13, 14, 15).

American Society of Anesthesiologists (ASA) in May 2015 made recommendations:

"Experts have long examined the effects of anesthesia on infants and toddlers, and many believe infants who undergo general anesthesia in their first year of life may be at higher risk of developmental and learning issues. New work suggests that infants undergoing some types of surgery could have better recovery if they receive regional anesthesia rather than general anesthesia" $(11,12,14,15)$.

The most referent studies for possible impact of anesthesia on childhood cognitive function in children, learning disabilities, the occurrence of ADHD (Attention deficit hyperactivity disorder) came out from Mayo Clinic, published in Anesthesiology/march/ 2009. The first study included 5,000 children born between 1976 and 1982 in Olmstead County, Minnesota. The study monitored male children, because the number of operative procedures in infants and children with hernioplasty are most to them. This study followed children with one, two or more surgery to 4 years of age, and their results in reading, writing, mathemathics tests cognitive problems up to 19 years of age $(11,12)$. Children who received two or more anesthesia twofold increased risk in terms of thinking, speaking, reading, spelling, performing calculations. Dr. Robert Wilder and co-authors of this study noted thatžthe data are preliminary and do not necessarily suggest a direct or definitive causal link between anesthesia and learning disabilities, only an association. "We clearly have not demonstrated that anesthetics are the cause of learning disability," says Wilder. "We don't want this to alarm the public to the point they aren't giving children appropri- ate medical care." It could be dangerous to deny children surgery to spare them the anesthesia, Wilder says, since in most cases of pediatric surgery, the procedure is a necessary and potentially lifesaving one that cannot be avoided or postponed (13). Scientists from this department allude to a dose-dependent effect, i.e. how long the baby was anesthetized more likely to develop later problems with reading, writing and mathematics.

However experts are not ready to say that babies should not be given anesthesia "We do not want to delay the operation of a child who has need of it," said Dr. Solpicio Soriano, an anesthesiologist at Harvard Medical School and Children's Hospital in Boston "but we need more research and clinical trials to find new drugs and new combinations of drugs that would affect less later cognitive function of the child" $(12,13)$.

The second study was conducted on 5357 children born between 1976 and 1982 at Mayo Clinic, Rochester, Minnesota. These children were followed up to 19 years. age regarding the occurrence of ADHD disorder. It was revealed that children who received an anesthesia up to 2 years. age in $10.7 \%$ appeared ADHD disorder and those who had received 2 or more anesthetics to 2 years old this disorder occurred in $17.9 \%$. Children who did not receive anesthesia percentage of ADHD was $7.3 \%$. This suggests a possible link between anesthesia and the emergence of ADHD disorder.Dr. Randall Flick, from the Mayo Clinic suggests of the neurotoxityof nitrous oxide which is widely used in dental offices in the United States $(11,12,13)$.

Third major study from the Royal Children Hospital in Melbourne, Australia, was performed on 2900 children under 3 years of age who received more anesthesia. At 10 years of age they were assessed for learning ability, thinking, remembering, reasoning, use of language and the development of depression and aggression. It was found that these children have almost more than twice as likely to have a language disability .In particular, it increased the chance that a child would have trouble listening to and remembering spoken words. The researchers found no link between anesthesia and behavioral problems or attention, however (12). The major study from Taiwan performed on 3293 children which were exposed to general anesthesia before 3 yearsof age showed that there is no connection between anesthesia and attention deficit/hyperactivity disorder(ADHD) (16).

In addition to the relative lack of safety data, recent in vitro and in vivo studies have shown that the variety of anesthetic agents in children less than 3 years of age (neonates, infants, small children) cause neurotoxicity and possible long- adverse neurodevelopmental outcomes $(17,18,19,20)$. In response to this concerns, the Food and drug administration (FDA) and the 
International Research Society in anesthesia (IARS) started an initiative called Smart Tots (Strategies for Mitigating Anesthesia- Related Neuro Toxicity in Tots) which examine the effects of anesthesia on brain development. Smart Tots seeks to ensure that children under age 4 will be as safe as possible when they need anesthesia during surgery. Studies have shown that this is a period of significant brain development in young children (21). Also another two major prospective studies are ongoing in children: PANDA (Pediatric Anesthesia Neurodevelopment assessment Study) project is a large, multi-center study based at the Morgan Stanley Children's Hospital of New York at Columbia University. The project aims to examine two groups of children - those who have been exposed to anesthesia and those who have not - and assess their neurodevelopment and cognitive functions. The goal of the PANDA project is to add to the body of knowledge surrounding the important topic of the long term neurodevelopmental effects of anesthesia and surgery in infants and young children (1).

The second study is GAS study which is a multisite randomized controlled trial comparing neurodevelopment outcomes in infant receiving general anesthesia compared to spinal and other regional anesthetics to the stress response to surgery (15).

The director of the Division of Anesthesia, Analgesia and Addiction Products at FDA,Bob Rappaport says "Our hope is that research funded through Smart Tots will help us design the safest anesthetic regimens possible" and "this research can potentially foster the development of new and safer anesthetic drugs for use in pediatric medicine" $(21,22)$.

\section{Conclusion}

The most of the mentioned studies found that a procedure of anesthesia/surgery in children before 4 years old is possibly associated with later neurodevelopmental deficits, especially multiple times of exposure to anesthesia. Due to the limitation of retrospective studies, prospective studies are needed to determine whether the association between anesthesia/surgery and neurodevelopmental deficits is causative.

\section{Conflict of interest}

The author declares no conflict of interest.

\section{Abbreviations}

GABA receptors - gamma-aminobutyric acid receptors

ASA - American Association of Anesthesiologists

NMDA receptors - N-methyl-D-aspartatereceptors

FDA - Food and Drug Administration

IARIS - International Research Society in anesthesia

PANDA - Pediatric Anesthesia Neurodevelopment assessment

GAS - Multi-site Randomized Controlled Trial Comparing Regional and General Anesthesia for Effects on Neurodevelopmental Outcome and Apnea in Infants

\title{
Sažetak
}

\section{OPŠTA ANESTEZIJA: DA LI JE BEZBEDNAZA NOVOROĐENČAD, ODOJČAD I MALU DECU?}

\author{
Nancheva Jasminka, ${ }^{1}$ Andonovski Alan, ${ }^{1}$ Kamnar Victor, ${ }^{1}$ Georgieva Daniela, ${ }^{1}$ \\ Nanceva Andrea, ${ }^{2}$ Georgiev Antonio ${ }^{3}$ \\ ${ }^{1}$ University Clinic for Orthopaedic surgery, Clinical Center "Mother Teresa", Medical Faculty, \\ University "St. Kiril and Metodij", Skopje, R. Macedonia \\ ${ }^{2}$ General Hospital "8 mi Septemvri", Skopje, R. Macedonia \\ ${ }^{3}$ PHO Cardiology - Prima, MIT University, Skopje, R. Macedonia
}

Izloženost neonatusa, odojčadi i male dece opštoj anesteziji postaje sve češća pojava. Sakupljanje prekliničkih podataka ukazuje da je izloženost, često primenjivanim opštim anesteticima, tokom ključnog perioda za razvoj mozga u populaciji (između kasnog gestacionog period do 3-4 godine života), može dovesti do apoptotskih neurodegenerativnih promena, gubitka sinapsi i kognitivnih i neurobihevioralnih deficita, koji ostaju prisutni i tokom sazrevanja organizma. Nova is- trazivanja savetuju da odojčad i mala deca, koja su podvrgnuta operaciji, mogu da imaju bolji oporavak, ako dobijaju regionalnu anesteziju pre nego ako su uvedena u opštu anesteziju. Kao odgovor na ovaj problem, FDA (Food and drug administration) i IARS (International Research Society in anesthesia) su započeli kampanju nazvanu Smart Tots (Strategies for Mitigating Anesthesia- related neuro Toxicity in Tots), koja izučava efekte anestezije na razvoj mozga. Takođe dve 
prospektivne studije su u toku: PANDA (Pediatric Anesthesia Neurodevelopment assessment Study) projekat je velika, multicentrična studija u Morgan Stanley dečjoj bolnici u Njujorku, na Kolumbija Univerzitetu i još jedna, GAS studija, koja upoređuje neurološke razvojne ishode kod odojčadi, koja su podvrgnuta opštoj

\section{REFERENCES}

1. Sun LS, Li G, Dimaggio C et al. Anesthesia and neurodevelopment in children: time for an answer? Anesthesiology. 2008; 109: 757-61.

2. Jevtovic-Todorovic V, Hartman R. E, Izumi Y et al Early exposure to common anesthetic agents causes widespread neurodegeneration in the developing rat brain and persistent learning deficits. J Neurosci. 2003; 23(3): 876-82.

3. Lunardi N, Ori C, Erisir A, Jevtovic-Todorovic V. General anesthesia causes long-lasting disturbances in the ultrastructural properties of developing synapses in young rats. Neurotox Res. 2010; 17(2): 179-88.

4. De Roo M, Klauser P, Briner A et al. Anesthetics rapidly promote synaptogenesis during a critical period of brain development. PLoS One. 2009; 4(9): e7043.

5. Briner A, De Roo M, Dayer A, Muller D, Habre W, Vutskits L. Volatile anesthetics rapidly increase dendritic spine density in the rat medial prefrontal cortex during synaptogenesis. Anesthesiology. 2010; 112(3): 546-56.

6. Crosby G, Culley D.J, Patel PM. At the sharp end of spines: anesthetic effects on synaptic remodeling in the developing brain. Anesthesiology. 2010; 112(3): 521-3.

7. Weiss M, Gerber AC. Rapid sequence induction in children - it's not a matter of time. Paediatr Anaesth. 2008; 18(2): 97-9.

8. Zdravkovic I, Jankovic R. Safe extubation and reintubation in operatory room and ICU patients. Sanamed. 2014; 9(1): 89-98

9. Peiris K, Fell D. The prematurely born infant and anaesthesia. ContinEducAnaesthe Critical Care Pain. 2009; 9(3): 73-7.

10. Brett CM, Davis PJ, Bikhazi G. Anaesthesia for neonates and premature infants. In: Motoyama EK, Davis PJ, editors Smith's Anesthesia for Infants and Children. Philadelphia: Mosby Elsevier. 2006; p. 521-70.

11. Sprung J, Flick RP, Katusic SK et al. Attention deficit/hyperactivity disorder after early exposure to procedures requiring general anesthesia. Mayo Clinic Proc. 2012; 87(2): 120-9.

12. American Society of Anesthesiologists (ASA). Researchers determine best anesthesia option for infants. Science- anesteziji u poređenju sa odojčadima podvrgnutim spinalnoj ili drugim oblicima regionalne anestezije.

Otkrića ovih studija pomoći će istraživačima da dizajniraju najbezbedniji anesteziološki protokol i da razviju novi i bezbedniji anestetik za upotrebu u pedijatriji.

Daily. ScienceDaily, 19 May 2015. <www.sciencedaily.com/releases/2015/05/150519121524.htm>.

13. Wilder RT, Flick RP, Sprung J et al.Early exposure to anesthesia and learning disabilities in a population- based birth cohort. Anesthesiology. 2009; 110(4): 796-804.

14. Gupta A, Saha U. Spinal anesthesia in children. J Anaesthesiol Clin Pharmacol. 2014; 30(1): 10-8.

15. Davidson AJ, Disma N, de Graaff JC, et al. Neurodevelopmental outcome at 2 years of age after general anaesthesia and awake-regional anaesthesia in infancy (GAS): an international multicentre, randomised controlled trial. Lancet. 2016; 387(10015): 239-50.

16. Ko WR, Liaw YP, Huang JY et al. Exposure to general anesthesia in early life and the risk of attention deficit/hyperactivity disorder development:a nationwide, retrospective matched-cohort study. Paediatr Anaesth. 2014; 24(7): 741-8.

17. Dimaggio C, Sun LS, Li G. Early childhood exposure to anesthesia and risk of developmental and behavioral disorders in a sibling birth cohort. Anesth Analg. 2011; 113(5): $1143-51$

18. Flick RP, Katusic SK, Colligan RC et al. Cognitive and behavioral outcomes after early exposure to anesthesia and surgery. Pediatrics. 2011; 128(5): e1053-61.

19. Frawley G, Bell G, Disma Net al. Predictors of Failure of Awake Regional Anesthesia for Neonatal Hernia Repair: Data from the General Anesthesia Compared to Spinal Anesthesia Study - Comparing Apnea and Neurodevelopmental Outcomes. Anesthesiology. 2015; 123(1): 55-65.

20. Davidson AJ, Morton SN, Arnup JS, et al.Apnea after Awake Regional and General Anesthesia in Infants: The General Anesthesia Compared to Spinal Anesthesia Study - Comparing Apnea and Neurodevelopmental Outcomes, A Randomized Controlled Trial. Anesthesiology. 2015; 123(1): 38-54.

21. Ramsay JG, Rappaport BA. Smart Tots: multidisciplinary effort to determine anesthetic safety children. Anesth Analg. 2011; 113(5): 963-4.

22. Nasr V, Davis JM. Anesthetic use in newborn and infants:the urgent need for rigorous evaluation. Pediatr Res. 2015; 78(1): $2-6$

\section{Correspondence to / Autor za korespondenciju}

Assoc. Prof. dr Jasminka Nancheva,

Clinic for Orthopaedic Surgery

Medical Faculty, University "St. Kiril and Metodij"

17 Mother Tereza, 1000, Skopje,

Rep. of Macedonia

$\mathrm{mob} /++38970365291$

e-mail:jasminkananceva@yahoo.com 